\title{
RESEARCH NOTE \\ Simultaneous detection of CTV, CEVd and HSVd using Arizona 861 S1 Citron and RT-PCR
}

\author{
Rocío Camps, Mónica Castro, and Ximena Besoain \\ Facultad de Agronomía, Pontificia Universidad Católica de Valparaíso. Casilla 4-D, Quillota, Chile.
}

\begin{abstract}
R. Camps, M. Castro, and X. Besoain. 2014. Simultaneous detection of CTV, CEVd and HSVd using Arizona 861 S1 Citron and RT-PCR. Cien. Inv. Agr. 41(2): 255-261. Citrus tristeza virus (CTV), Citrus exocortis viroid (CEVd) and Hop stunt viroid (HSVd) are pathogens that affect citrus trees in Chile. The simultaneous use of a rapid diagnostic method with the effective cleaning of infected budwood is a powerful preventative method for controlling viral diseases. The objective of this study was the multiple detection of CTV, CEVd, and HSVd, through bio-amplification in Arizona 861-S1 citron plants, combined with two incubation temperatures and multiple RT-PCR in two steps. Citron indicator plants were inoculated with the three pathogens, both individually and simultaneously, with four un-inoculated plants as controls. After four months of incubation at the two different temperatures, both the multiple and individually inoculated plants showed symptoms associated with these pathogens, which were subsequently corroborated through the use of multiple RT-PCR in two steps. This diagnostic method could be employed as an efficient, cost-effective alternative to the methods that are currently in use for detecting CTV, CEVd and HSVd, nevertheless its effectiveness should also be evaluated with tests using different isolates of these pathogens.
\end{abstract}

Key words: CEVd, citrus, CTV, diagnostic methods, HSVd, rapid detection.

\section{Introduction}

Tristeza is the most serious viral disease affecting citrus trees worldwide. It is caused by Citrus tristeza virus (CTV) and the principal symptoms in Mexican lime indicator plants include vein clearing, leaf cupping and stem-pitting (Roistacher, 1991). In Chile, CTV is present in almost all of the citrus-producing regions (Besoain, 2008). Citrus trees are hosts of five viroid species of the Pospiviroidae family, with two important causal

Received January 16, 2014. Accepted July 11, 2014. Corresponding author: xbesoain@ucv.cl agents: Citrus exocortis viroid (CEVd) and Hop stunt viroid (HSVd) (that includes CCaVd-IIa and -IIb, the latter causes a disease called cachexia). The exocortis viroid is distributed worldwide, but is rarely severe enough to cause death of infected trees. The major symptoms include bark scaling, general decline, decreased size and stunting, and the classic symptom of leaf epinasty, which can be observed in inoculated Arizona 861-S1 citron (Citrus medica L.) indicator plants (Roistacher, 1991). In Chile, the causal agent has been found distributed from Tarapacá to the Metropolitan Region (Valenzuela et al., 2000). Cachexia was first described in Orlando (Florida, USA) in 1988, 
on Parson's Special mandarin with symptoms characterized by the presence of pitting, and gum-spotting near the graft union (Roistacher, 1991). In Chile, this disease has been reported to affect lemons grafted on C. macrophylla and mandarin grafted on Carrizo citrange (Valenzuela et al., 2000).

The diagnosis of viroid diseases in citrus is accomplished through biological indexing, using indicator plants such as Arizona $861 \mathrm{~S} 1$ citron and Parson's Special mandarin. This method is reliable but, unfortunately, the observation period for symptoms necessary for an accurate diagnosis requires an incubation period of at least 14 months and plants must be held at temperatures that oscillate between 28 and $36^{\circ} \mathrm{C}$. Another method is to combine the Arizona citron indicator plant with sequential electrophoresis on polyacrylamide gels (sPAGE) (Durán-Vila et al., 1993). This method requires only 3 to 4 months but is difficult in practice due to the sequential electrophoresis. However, there are studies in which biological testing methods have been combined with bioamplification of the causal agents and molecular analyses to achieve a very specific and sensitive diagnosis with a shorter incubation period and thus a more rapid detection and diagnosis (DuránVila et al., 1993). The RT-PCR technique is the most commonly used alternative for detecting viruses and viroids that affect citrus (Yang et al., 1992). Various publications have proposed a multiple RT-PCR method for detecting the major citrus viroids in a single reaction (with reverse transcription and amplification within the same tube), which have given satisfactory results in decreasing plant contamination, work-time and cost (Yang et al., 1992; Ito et al., 2002a; Bernard and Durán-Vila, 2006). Other authors have proposed detection using multiple RT-PCR only for viruses that affect Prunus spp. (Jorosova and Kundu, 2010). Only one study has proposed a method for multiple detection for a combination of viruses and viroids that affect citrus, where detection focused on Citrus tatter leaf virus (CTLV) and the major citrus viroids (Ito et al., 2002b). Currently, no other studies have been published proposing a method for the simultaneous detection of CTV and the CEVd and HSVd viroids. This study therefore proposes to simultaneously amplify CEVd and HSVd in Arizona 861-S1 citron/rough lemon using a combination of high incubation temperatures to encourage the development of the viroids and two months of lower incubation temperatures to encourage the development of CTV, along with a method of reverse transcription specific for the viroids and one specific for CTV, and finally the multiple PCR to achieve the simultaneous detection of the three pathogens.

The objective of this study was to validate the technique of combining bio-amplification in Arizona 861-S1 citron at two incubation temperatures and RT-PCR in two steps for the simultaneous detection of the virus and viroids in samples from infected citrus.

\section{Materials and methods}

\section{Inoculation of indicator plants}

The biological testing was conducted with plants at the diagnostic greenhouse of the Citrus Certification Program at the Experimental Station La Palma (EELP) of the Faculty of Agronomy of the Pontificia Universidad Católica de Valparaíso (FA-PUCV). Three infected reservoir plants from the Virus and Viroid Citrus Germplasm Bank were selected: the 315-5 isolate of CTV taken from Mexican Lime, the 6-1 isolate of HSVd taken from Génova Lemon, and the 1591 isolate of CEVd taken from Génova Lemon. Virus-free Arizona 861-S1 citron plants grafted onto rough lemon (plants $30 \mathrm{~cm}$ high) were used as the indicator plants, with the five inoculation treatments described in Table 1. Each treatment had four replicates.

For each of the citron indicator plants, four shoots were selected from each of the infected reservoir trees (obtained around four sides of the plant). Two 
Table 1. Inoculation treatments on Arizona 861-S1 Citron plants.

\begin{tabular}{lll}
\hline Treatment $\mathrm{N}^{\circ}$ & Isolate & Pathogen Inoculated \\
\hline 1 & $315-5$ & CTV \\
2 & $6-1$ & HSVd \\
3 & $159-1$ & CEVd \\
4 & $315-5 ; 6-1 ;$ & CTV- HSVd- CEVd \\
5 & $159-1$ & Virus and viroid-free plant \\
\hline
\end{tabular}

patches per shoot (eight total) were grafted onto the indicator plants in each of the treatments. For the plants in the multiple inoculation treatment, a total of eight patches were selected for each plant, consisting of three branches from the CEVd reservoir plant, three branches from the HSVd reservoir plant (three for viroids because they are not uniformly distributed in infected plants (Durán-Vila et al., 1991)), and two branches from the CTV reservoir plant, grafting one patch from each branch onto the indicator plants (resulting in eight grafted patches per plant).

The inoculated plants were then incubated in the greenhouse for two months at $28^{\circ} \mathrm{C}$ and then for two months at temperatures fluctuating between 18 and $26^{\circ} \mathrm{C}$, and maintained under optimal growth conditions. After the incubation period, sample materials for subsequent RNA extraction and RT-PCR were collected from each plant, with samples from leaf parts that appeared to be affected by disease symptoms in each treatment.

\section{Viral RNA extraction}

Molecular testing was performed using RNA extraction from material from each of the reservoir plants and the inoculated indicator plants after four months of incubation. The RNA was extracted using the RNeasy ${ }^{\circledR}$ plant Mini Kit (Qiagen Hilden, Germany).

\section{RT-PCR for pathogens}

For detection of CTV, the methodology described by Olmos et al. (1999) was performed with the primers reported by Hilf et al. (2005) corresponding to the sequence of the coat protein of isolate T36, T36CP (F)5'ATGGACGACGAAACAAAGAAAT TG3'; (R)5'TCAACGTGTGTTGAATTTCCCA3' (672bp). RT-PCR was performed using $5 \mu \mathrm{L}$ of RNA, containing 10X Taq DNA Polymerase Buffer (Qiagen Hilden, Germany), $15 \mathrm{mM}$ the $\mathrm{MgCl}_{2}, 1 \mu \mathrm{M}$ of each primer, $250 \mu \mathrm{M}$ of dNTP, 0.25 units of AMV-RT (New England BioLabs UK.), $40 \mathrm{U}$ of RNase Inhibitor (New England BioLabs UK), and 0.5 units of Taq polymerase (Quiagen Hilden, Germany).

The amplification conditions consisted of predenaturation at $42{ }^{\circ} \mathrm{C}$ for $45 \mathrm{~min}$, followed by a step of $94{ }^{\circ} \mathrm{C}$ for $2 \mathrm{~min}, 30$ cycles of $94{ }^{\circ} \mathrm{C}$ for $30 \mathrm{sec}, 55^{\circ} \mathrm{C}$ for $30 \mathrm{sec}, 72{ }^{\circ} \mathrm{C}$ for $45 \mathrm{sec}$, and a final extension of $72{ }^{\circ} \mathrm{C}$ for $5 \mathrm{~min}$. The bands were observed on a $2 \%$ agarose gel.

For the detection of CEVd and HSVd, the methodology described by Yang et al. (1992) was followed, where the reactions took place separately with $3 \mu \mathrm{L}$ of RNA, $1 \mu \mathrm{L}$ of the primer reverse and 3 $\mu \mathrm{L}$ of water. This was incubated at $100{ }^{\circ} \mathrm{C}$ for 5 min, put on ice for $2 \mathrm{~min}$, and then held at room temperature for $1 \mathrm{~h}$. A mixture, containing the primer, was added to $20 \mu \mathrm{L}$ of the DNAc, $1 \mu \mathrm{L}$ buffer M-MLV (New England BioLabs UK), 1 $\mu \mathrm{L}$ dNTP 1.25, $40 \mathrm{U}$ of RNase Inhibitor (New England BioLabs UK) and 400 U of M-MLV reverse transcriptase (New England BioLabs UK), adjusted to a volume of $50 \mu \mathrm{L}$ with sterilized water, and the reaction was incubated at $42{ }^{\circ} \mathrm{C}$ for $1 \mathrm{~h}$.

The amplification consisted of one aliquot of 5 $\mu \mathrm{L}$ from the previous reaction added to a mixture that contained: 10X Taq DNA Polymerase Buffer (Quiagen Hilden, Germany), 15 mM the $\mathrm{MgCl}_{2}, 200 \mu \mathrm{M}$ each of dNTP, $2.5 \mathrm{U}$ of Taq polymerase (Quiagen Hilden, Germany), and $2 \mu \mathrm{M}$ of each primer. The primers used for exocortis were described by Gross et al. (1982) (R)-5'CCGGGGATCCCTGAAGGACTT3' (F)-5'GGAAACCTGGAGGAAGTCGAG3'. The primers used for cachexia were de- 
scribed by Sano et al., (1988) (R)5'CCGGGGCTCCTTTCTCAGGTAAGT3' (F)-5' GGCAACTCTTCTCAGAATCCAGC3'.

The amplification consisted of $94^{\circ} \mathrm{C}$ for $3 \mathrm{~min}, 40$ cycles of $94{ }^{\circ} \mathrm{C}$ for $1 \mathrm{~min}, 55^{\circ} \mathrm{C}$ for $1 \mathrm{~min}, 72^{\circ} \mathrm{C}$ for $1 \mathrm{~min}$, and a final extension of $72^{\circ} \mathrm{C}$ for $7 \mathrm{~min}$.

\section{Multiple RT-PCR}

For the multiple RT-PCR, two steps were used (the synthesis of DNAc of CTV was conducted separately from the CEVd and HSVd), which followed the procedure previously described for each pathogen. The PCR was the same for the three pathogens, consisting of one aliquot of $5 \mu \mathrm{L}$ of the reaction mixture (obtained from the reverse transcriptase) to which was added a mixture containing: $5 \mu \mathrm{L}$ the 10X Taq DNA Polymerase Buffer (Quiagen Hilden, Germany), $15 \mathrm{mM}$ the $\mathrm{MgCl}_{2}, 200 \mu \mathrm{M}$ of each dNTP $2.5 \mathrm{U}$ of Taq polymerase (Quiagen Hilden, Germany), $1 \mu \mathrm{M}$ of each primer of CTV, $0.5 \mu \mathrm{M}$ of each primer of CEVd and $0.5 \mu \mathrm{M}$ of each primer of HSVd.

The amplification consisted of $94^{\circ} \mathrm{C}$ for $3 \mathrm{~min}$, 40 cycles of $94{ }^{\circ} \mathrm{C}$ for $1 \mathrm{~min}, 55^{\circ} \mathrm{C}$ for $30 \mathrm{~min}$, $72{ }^{\circ} \mathrm{C}$ for $1 \mathrm{~min}$, and a final extension of $72{ }^{\circ} \mathrm{C}$ for $7 \mathrm{~min}$.

The PCR products were observed on a $2 \%$ agarose gel and exposed to ultraviolet light with GelRedTM (Biotium, Inc., Hayward, CA, USA).

The PCR products were purified and sequenced in both directions by Macrogen (Macrogen Inc., Geumchen-gu, South Korea). Sequences were edited and assembled using CodonCode Aligner version 4.2 (CodonCode Corporation, Centerville MA. USA). The sequences of each pathogen were compared using the GenBank database and basic local alignment search tools (Blast) for nucleotide analyses. The identification was confirmed with $>98 \%$ similarity to the virus or viroid deposited in GenBank.

\section{Results}

Four months after the inoculation, disease symptoms were observed in all of the inoculated treatments on the Arizona 861-S1 citron plants, and for those inoculated with CTV, the vein clearing symptom was particularly clear (Figure $1 \mathrm{a}$ ). In plants inoculated with CEVd, the characteristic symptoms of severe epinasty and stunting were observed (Figure $1 \mathrm{~b}$ ). In plants inoculated with HSVd, the symptoms of leaf break (Figure $1 \mathrm{c}$ ) were observed. In the multiple-inoculated plants, symptoms of all three diseases were observed: leaf epinasty, leaf break and vein clearing (Figure 1). The healthy control plants show no symptoms through the end of the assay.

Eight months post-inoculation, the RT-PCR technique was capable of detecting both the individual and multiple infections of the three pathogens evaluated (Figure $2 \mathrm{C}, \mathrm{D}, \mathrm{E}$ and F), which supported the presence of the symptoms observed in the inoculated plants. The expected size of PCR products was found for the three pathogens: CTV (672 bp), CEVd (371 bp), and HSVd (269 bp). In the healthy controls, no bands were observed (Figure 2B), and in the multiple inoculation treatment, all three bands were observed from a single PCR (Figure 2F).

The DNA sequences generated in this study have been deposited in GenBank under the accession numbers: KF973205, KJ139986, and KJ139987.

\section{Discussion}

The observation of vein clearing in the Arizona 861-S1 citron plants inoculated with CTV coincide with the symptoms described for Mexican limes by Roistacher (1991); however, these symptoms had not been previously described for Arizona 861-S1 citron plants (Roistacher 1991). The symptomatology of severe epinasty and stunting in plants inoculated with exocortis agrees with the description by Roistacher (1991) for Arizona 


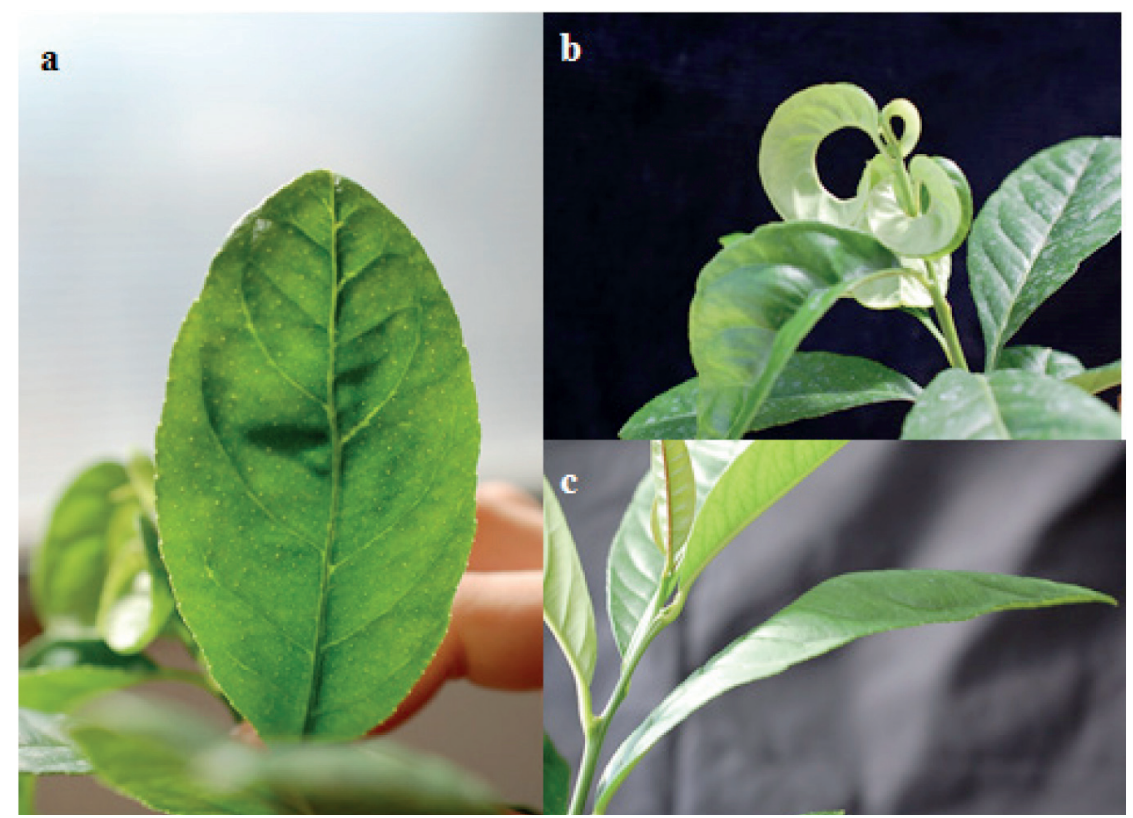

Figure 1. Arizona 861-S1 Citron grafted on rough lemon with multiple inoculation of CTV (isolate 315-5), CEVd (isolate 159-1) and HSVd (isolate 6-1) showing three symptoms a) symptoms of vein clearing, b) symptoms of leaf epinasty, and c) symptoms of leaf break.

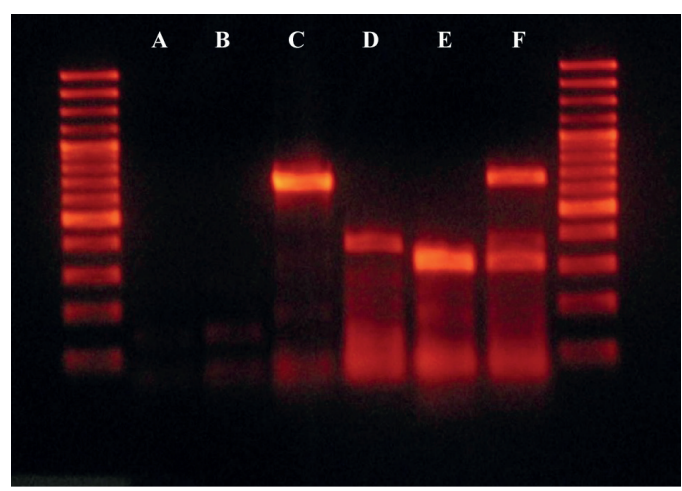

Figure 2. Agarose gel electrophoresis with products of RT-PCR. Lane A: control with water; B: Healthy plant; C: Citron inoculated with CTV (672 pb); D: Citron inoculated with CEVd (371 pb); E: Citron inoculated with HSVd (269 $\mathrm{pb})$; and F: Citron with multiple inoculation.

861-S1 citrons. The symptoms of leaf break and petiole necrosis observed on plants inoculated with cachexia agree with those described by Durán-Vila et al. (1991). It is important to note that the reverse transcriptase methodology was separated for viruses and viroids and that, unlike the viruses, the viroids required high temperatures for denaturation of their secondary structure (Bernard and Durán-Vila, 2006), while this study was conducted with a combined methodology using only PCR.

The presence of symptoms on indicator plants facilitated the selection of samples for later molecular analysis. This demonstrates that the prior inoculation of Arizona 861-S1 citron plants is more efficient and improves the effectiveness of the technique than when samples are simply taken from problem plants, as it is known that viroids are not uniformly distributed in infected plants (Durán-Vila et al., 1991). Therefore, placing of patches on various sectors of the plants that will be analyzed improves the probability of finding the pathogen.

There are many methods for the detection of citrus viruses and viroids, some are quite lengthy, as in the case of biological tests which require long incubation periods to be certain of observed symptoms. In addition, these tests require specific indicator plants for each pathogen (Roistacher, 1991; Durán et al., 1993), which must be combined with the technique of sequential polyacrylamide gel electrophoresis (sPAGE). The most recent method 
for the detection of pathogens is PCR real time; however, this technique is still quite expensive, which is the principal problem for implementing its routine use in laboratories (López et al., 2003), though for detecting viral diseases in citrus, the results have been shown to be fast and reliable (Rizza et al., 2009; Loconsole et al., 2010).

In this study, we proposed an alternative methodology to those currently in use, where we combined biological testing with a shorter incubation period and simultaneous observation of symptoms on single indicator plants, in combination with virus/ viroid detection using simultaneous RT-PCR. The effectiveness of this method should be further evaluated using different isolates of these pathogens.
The results obtained in this study contribute to a secure diagnosis that could be utilized in citrus certification procedures, decreasing both the costs and detection times and aid in the creation of a reliable diagnostic tool for detecting viral diseases.

\section{Acknowledgements}

Financial support was provided by the Vicerrectoría de Investigación y Estudios Avanzados of the Pontificia Universidad Católica de Valparaíso (VIREA-PUCV project DI 037.412/2012). We would also like to thank the Propagation Laboratory of the Pontificia Universidad Católica de Valparaíso for the use of the growth chamber.

\title{
Resumen
}

\begin{abstract}
R. Camps, M. Castro y X. Besoain. 2014. Detección simultanea de CTV, CEVd y HSVd a través de Cidro Arizona 861-S1 y RT-PCR. Cien. Inv. Agr. 41(2):255-261. El virus de tristeza de los cítricos (CTV), el viroide de la exocortis (CEVd) y el viroide Hop Stunt viroid (HSVd), son patógenos que afectan a plantas de cítricos en Chile. El uso de un método de diagnóstico rápido junto con la limpieza eficaz de portainjertos infectados, es una potente herramienta preventiva en el control de las enfermedades virales. El objetivo de este estudio fue detectar de forma múltiple CTV, CEVd y HSVd con el método de bio-amplificación en Cidro Arizona 861-S1, combinado con dos temperaturas de incubación y RT-PCR, en dos pasos. Se inocularon plantas de Cidro Arizona 861-S de forma individual y simultánea con los tres patógenos. Luego de cuatro meses de incubación a dos diferentes temperaturas, las plantas inoculadas de forma individual y de forma múltiple mostraron síntomas asociados con estos patógenos que posteriormente fueron corroborados mediante RT-PCR múltiple en dos pasos. Este método resulta eficaz y rentable al ser una detección simultánea, y podría ser utilizado de forma alternativa a los que están actualmente en uso para la detección de CTV, CEVd y HSVd, sin embargo, su eficacia también debe ser evaluada usando diferentes aislados de estos patógenos.
\end{abstract}

Palabras clave: CEVd, Cítricos, CTV, HSVd, método de diagnóstico, rápida detección.

\section{References}

Bernard, L., and N. Durán-Vila. 2006. A novel RT-PCR approach for detection and characterization of citrus viroids. Molecular and Cellular Probes 20:105-113.

Besoain, X. 2008. Incidencia, Caracterización y epidemiologia del virus de la tristeza de los cítricos en Chile. Tesis Doctoral. Universidad
Politécnica de Valencia. Escuela técnica superior de ingenieros agrónomos Valencia, España. 129 pp.

Durán-Vila, N., J.A. Pina, M-I. Molins, and L. Navarro. 1991. A new indexing method for cachexia. In: Proc $11^{\text {th }}$ conf. International Organization of Citrus Virologists (IOCV): IOCV Riverside, Australia. p. 224-229. 
Durán-Vila, N., J.A. Pina, and L. Navarro. 1993. Improved indexing of citrus viroids. In: Proc $12^{\text {th }}$ conf. International Organization of Citrus Virologists (IOCV): IOCV Riverside, California. p. 202-211.

Gross, H.J., G. Krupp, H. Domdey, M. Raba, P. Jank, and C. Lossow. 1982. Nucleotide sequence and secondary structure of citrus exocortis and Chysanthemum stunt viroid. European Journal of Biochemistry 121:249-257.

Hilf, M. E., V. Mavrodieva, and S. Garnsey. 2005. Genetic marker analysis of global collection of isolates of citrus tristeza virus: Characterization and distribution of CTV genotypes and association with symptoms. Phytopathology 95:909-917.

Ito, T., H. Ieki, K. Ozaki, T. Iwanami, K. Nakahara, T. Hataya, M. Isaka, and T. Kano. 2002a. Multiple citrus viroids in citrus from Japan and their ability to produce exocortis-like symptoms in citron. Phytopathology 92:542-547.

Ito, T., I. Hiroyuki, and O. Katsumi. 2002b. Simultaneous detection of six citrus viroids and Apple stem grooving virus from citrus plants by multiple reverse transcription polymerase chain reaction. Journal of Virological Methods 106:235-239.

Jorosova, J., and J.K. Kundu. 2010. Simultaneous detection of stone fruit tree viruses by onestep multiplex RT-PCR. Scientia Horticulturae 125:68-72.

Loconsole, G., M. Saponari, and V. Savino. 2010. Development of real-time PCR based assays for simultaneous and improved detection of citrus viruses. Eur. J. Plant Pathology 128:251-259.

López, M., E. Bertolini, A. Olmos, P. Caruso, M.T. Gorris, P. Lolp, R. Penyalver and M. Cambra. 2003. Innovative tools for detection of plant pathogenic viruses and bacteria. Int. Microbiol 6:233-243.

Olmos, A., M. Cambra, O. Esteban, M. Gorris, and E. Terrada. 1999. New device and method for capture, reverse transcription and nested PCR in a single closed-tube. Nucleic Acids Research 27:1564-1565.

Rizza, S., G. Nobile, M. Tessitori, A. Catara, and E. Conte. 2009. Real time RT-PCR assay for quantitative detection of Citrus Viroid III in plant tissues. Plant Pathology 58:181-185.

Roistacher, C.N. 1991. Graft-Transmissible diseases of citrus. Handbook for detection and diagnosis. Roma IOCV FAO 286 pp.

Sano, T., T. Hataya, and E. Shikata. 1988. Complete nucleotide sequence of a viroide isolated from Etrog citron, a new member of hop stunt viroide Group. Nucleic Acid Res 16:347.

Valenzuela, M., X. Besoain, M. Castro, C. Pizarro, and J. Ballester-Olmos. 2000. El problema de la Cachexia en Chile. Fitopatología 35:105110.

Yang, X., A. Hadidi, and S.M. Garnsey. 1992. Enzymatic cDNA amplification of citrus Exocortis and Cachexia viroids from infected citrus host. Phytophathology 82:279-285. 
